\title{
SCREENING OUT OF WHEAT VARIETIES AGAINST ARSENIC CONTAMINATED SOIL AND IRRIGATION WATER
}

\author{
S. NOOR ${ }^{* 1}$, N.C. SHIL ${ }^{1}$, S. MAHMUD ${ }^{2}$, M. B. HOSSAIN ${ }^{3}$ AND A.A. HASAN ${ }^{3}$ \\ ${ }^{1}$ Bangladesh Agricultural Research Institute, Joydebpur, Gazipur ${ }^{2}$ Bangabandhu Sheikh Mujibur \\ Rahman Agricultural University, Salna, Gazipur ${ }^{3}$ Bangladesh Agricultural Research Council, \\ Farmgate, Dhaka, Bangladesh
}

\begin{abstract}
Field trials on wheat were conducted at severely arsenic contaminated areas of Jessore (Chowgacha and Sharsha), Faridpur (Poranpur) and also at low contaminated Shatkhira (Benerpota) during 2010-2011 and 2011-12. The major objective of the study was to screening out of arsenic tolerant wheat varieties. Five varieties of wheat viz. Shatabdi, Bijoy, Prodip, BARI Gom-25 and BARI Gom-26 were tested. Total arsenic contents in the soils were 36.4, 32.8, 28.5 and $6.8 \mathrm{mg} \mathrm{kg}^{-1}$ for Sharsha, Chowgacha, Poranpur and Benerpota, respectively. Irrigation waters contained 0.346, 0.272, 0.238 and $0.140 \mathrm{mg} \mathrm{L}^{-1}$ arsenic for Sharsha, Chowgacha, Poranpur and Benerpota, respectively. No significant variations in yield and yield components among the tested wheat varieties was observed despite of arsenic contaminations in the irrigation water and soil. The variety, Prodip contains 0.043 and $0.028 \mathrm{mg} \mathrm{kg}^{-1}$ arsenic in straw and grain, respectively, which was lower than the other tested varieties. But arsenic contents in all of the tested wheat varieties were found much lower than that of the permissible limit ( $\left.1 \mathrm{mg} \mathrm{kg}^{-1}\right)$. The transfer coefficient (TC) of arsenic from soil to above ground parts (straw + grain) of wheat varied slightly among the tested varieties where Prodip showed the lowest TC (0.0015-0.0018). However, BARI Gom-24 (Prodip) performed better in terms of arsenic content, uptake, biomass, yield and transfer coefficient and thus can be regarded as arsenic tolerant to a considerable extent.
\end{abstract}

Key words: Arsenic contamination, Wheat, Tolerant variety, Yield, Permissible limit

\section{Introduction}

Bangladesh agricultural sector is facing a big challenge to cope with the potential impact of arsenic (As) contamination in soil and water and its probable entry into the food chain. The average background concentration of arsenic in soils of Bangladesh is $<10 \mathrm{mg} \mathrm{kg}^{-1}$ but in some areas where soils receive As contaminated ground water irrigation, the As concentration recorded to be as high as $80 \mathrm{mg} \mathrm{kg}^{-1}$. Sandy sediments contained 3-7 mg $\mathrm{kg}^{-1}$ (median: $5 \mathrm{mg} \mathrm{kg}^{-1}$ ), clayey sediments contained 4-18 $\mathrm{mg} \mathrm{kg}^{-1}$ (median: $9 \mathrm{mg} \mathrm{kg} \mathrm{kg}^{-1}$, whereas peaty and peaty clay sediments contained 20-111 $\mathrm{mg} \mathrm{kg}^{-1}$ As (Yamazaki et al. 2003). Arsenic concentrations in irrigation water samples were many folds higher than

\footnotetext{
* Author for correspondence.
} 
FAO permissible limit for irrigation water $\left(0.10 \mathrm{mg} \mathrm{L}^{-1}\right)$. But $24 \%$ of the total irrigated boro rice in Bangladesh is grown in areas where ground water As is $>0.05 \mathrm{mg} \mathrm{L}^{-1}$ (Karim 2001). High ground water As (0.10 -0.20 $\left.\mathrm{mg} \mathrm{L}^{-1} ;>0.20 \mathrm{mg} \mathrm{L}^{-1}\right)$ was found in the central part of the country near the Padma and Meghna rivers. Use of arsenic contaminated irrigation water leads to soil contamination with high levels of arsenic. Crops receiving arsenic-contaminated irrigation-water take up this toxic element and accumulate it in different degrees depending on the species and variety. Soil As build up during boro season over the years may reduce the yield and increase the As uptake by grain and straw of rice (Van Green et al. 2006). Previous studies demonstrated a significant amount of arsenic uptake by rice (Duxbury et al. 2003 and Wang et al. 2006) and edible parts of vegetable crops (Alam et al. 2003). Williams et al. (2006) conducted extensive sampling of rice throughout Bangladesh collecting 330 samples of Aman rice and Boro rice and observed a positive correlation between As in the groundwater and As in the rice. This correlation was stronger for Boro rice than that of Aman rice. Arsenic concentrations in agricultural plants varied from 0.007 to about $7.50 \mathrm{mg} \mathrm{kg}^{-1}$ (Liao et al., 2005 and Dahal et al. 2008). Das et al. (2004) reported As contamination in vegetables collected from contaminated areas of Bangladesh. Farid et al. (2003) found higher amount of As (0.57 $\mathrm{mg} \mathrm{kg}{ }^{-1}$ ) in amranth. Presence of arsenic in plants and plant products usually does not exceed $1 \mathrm{mg} \mathrm{As} \mathrm{kg}^{-1}$ (Kiss et al. 1992). Wheat the second most cereal crop in Bangladesh is also cultivated in badly arsenic contaminated regions like Jessore and Faridpur. There is a general perception that upland crop like wheat may contain low amount of arsenic than that of rice. Physiological activities of wheat seedlings changed under As stress ( $\mathrm{Li}$ et al. 2007). Seed germination, biomass, root length and shoot height decreased, and As accumulation increased on early seedlings of six wheat varieties as concentration increased (Liu and Zhang 2007). Arsenic concentration in wheat grain varied from (0.013 $-0.086 \mathrm{mg} \mathrm{kg}-1$ ) when soil contained $11-29 \mathrm{mg} \mathrm{kg}^{-1}$ As in Europe (Zhao et al. 2010). The content and uptake of arsenic in wheat thus need to be thoroughly investigated. Again screening out of tolerant wheat varieties needs to be done for better adaptation in the affected areas. But such studies on wheat are very scanty. It is therefore felt necessary to know the arsenic concentration in and uptake by wheat and to screening out of arsenic tolerant varieties.

\section{Materials and Methods}

A screening study was conducted to observe the performance of wheat varieties grown in arsenic contaminated soil and with contaminated irrigation water. In case of first year (2010-2011), the study was conducted in Poranpur (Faridpur) and Benerpota (Satkhira) which represented AEZ 12 and 13, respectively. The initial level of total As in soil was $28.6 \mathrm{mg} \mathrm{kg}^{-1}$ at Poranpur while $6.8 \mathrm{mg} \mathrm{kg}^{-1}$ at Benerpota. The tested varieties were Shatabdi $\left(\mathrm{V}_{1}\right)$, Bijoy $\left(\mathrm{V}_{2}\right)$, Prodip $\left(\mathrm{V}_{3}\right)$ and BARI Ghom-26 $\left(\mathrm{V}_{4}\right)$. However, incase of second year (2011-2012), the study was conducted in highly contaminated area at Chowgacha and Sharsha of Jessore under AEZ 11 and also at Poranpur of Faridpur 
including one more variety (BARI Gom-25). The background level of total As in soil was 32.8, 36.4 and $28.5 \mathrm{mg} \mathrm{kg}^{-1}$ for Poranpur, Chowgacha and Sharsha, respectively (Table 1). Arsenic contents in irrigation waters were $0.272,0.346,0.238$ and $0.140 \mathrm{mg} \mathrm{L}^{-1}$ for

Table 1. Nutrient status and arsenic (As) contents in irrigation water and soils at the experimental sites.

\begin{tabular}{|c|c|c|c|c|c|}
\hline Item & & Loc & ation & & Critical level \\
\hline Soil properties & Poranpur & Benerpota & Chowgacha & Sharsha & \\
\hline $\mathrm{pH}$ & 7.6 & 7.8 & 7.2 & 7.3 & - \\
\hline Organic matter $\left(\mathrm{g} \mathrm{kg}^{-1}\right)$ & 15.4 & 11.1 & 13.2 & 16.0 & - \\
\hline Total-N (\%) & 0.06 & 0.05 & 0.08 & 0.09 & 0.12 \\
\hline Exchangeable Ca $\left(\mathrm{cmol} \mathrm{kg}^{-1}\right)$ & 11.6 & 10.4 & 13.8 & 12.1 & 2.0 \\
\hline Exchangeable $\mathrm{Mg}\left(\mathrm{cmol} \mathrm{kg}^{-1}\right)$ & 3.8 & 2.7 & 2.9 & 3.3 & 0.8 \\
\hline Exchangeable $\mathrm{K}\left(\mathrm{cmol} \mathrm{kg}^{-1}\right)$ & 0.21 & 0.26 & 0.18 & 0.14 & 0.12 \\
\hline Available P (mg kg-1) & 13.0 & 15.6 & 15.2 & 11.5 & 10 \\
\hline Available S (mg kg-1) & 16.2 & 19.2 & 18.4 & 13.5 & 10 \\
\hline Available $\mathrm{Zn}\left(\mathrm{mg} \mathrm{kg}^{-1}\right)$ & 0.52 & 0.32 & 0.36 & 0.64 & 0.60 \\
\hline Available Fe (mg kg$\left.{ }^{-1}\right)$ & 42.5 & 39.2 & 33.6 & 38.1 & 4.0 \\
\hline Available Mn (mg kg $\left.{ }^{-1}\right)$ & 6.1 & 4.8 & 4.3 & 5.4 & 1.0 \\
\hline Available B (mg kg-1) & 0.32 & 0.35 & 0.22 & 0.26 & 0.2 \\
\hline Total As content in soil $\left(\mathrm{mg} \mathrm{kg}^{-1}\right)$ & 28.5 & 6.8 & 36.4 & 32.8 & 20.0 \\
\hline $\begin{array}{l}\text { As content in irrigation water } \\
\left(\mathrm{mg} \mathrm{L}^{-1}\right)\end{array}$ & 0.272 & 0.140 & 0.346 & 0.238 & 0.100 \\
\hline
\end{tabular}

Poranpur, Chowgacha, Sharsha and Benerpota, respectively. The crop was fertilized with $\mathrm{N}_{120} \mathrm{P}_{30} \mathrm{~K}_{90} \mathrm{~S}_{15} \mathrm{Zn}_{2} \mathrm{~B}_{1} \mathrm{~kg} \mathrm{ha}^{-1}$ (BARC 2005). Two-third of nitrogen and all of phosphorus, potassium, sulphur, zinc and boron were applied as basal during final land preparation. The remaining one-third of nitrogen was applied at 21 days after sowing (DAS) then a light irrigation was applied. Crop was further irrigated at maximum tillering stage (50 DAS) and also at initial grain filling stage (72 DAS). The crop was harvested at its right stage of maturity. Data on yield and yield components were recorded accordingly.

Soil analysis: The collected samples were analyzed for total As content (Alam et al., 2001). The As content in soil and plant parts was determined after digestion with concentrated nitric acid and hydrogen peroxide mixture (2:1). An amount of $0.5 \mathrm{~g}$ sample was taken in digestion tube. Then $5 \mathrm{ml}$ of $12 \mathrm{M} \mathrm{HNO}_{3}$ was added in the tube and mixed with a watch glass or vapour recovery device and allowed to stand for over night. The sample was heated without boiling at $95^{0} \pm 5^{0} \mathrm{C}$ for $10-15$ hour and was allowed to cool and again $5 \mathrm{ml}$ of $12 \mathrm{M} \mathrm{HNO}_{3}$ was added, the cover was replaced, and sample was heated at $95^{\circ} \pm 5^{0} \mathrm{C}$ for 30 minutes. This step (addition of $5 \mathrm{ml}$ of conc. $\mathrm{HNO}_{3}$ ) was repeated until no brown fumes were given off by the sample. After completion of digestion with $\mathrm{HNO}_{3}$, the sample was allowed to cool. Then $2 \mathrm{ml}$ of water and $3 \mathrm{ml}$ of $30 \% \mathrm{H}_{2} \mathrm{O}_{2}$ were added, and the vessel was covered with a watch glass and returned to the heat source for warming and to start to peroxide reaction. Heating was continued until the effervescence subsides and then the vessel allowed cooling. Then $1 \mathrm{ml}$ of $30 \% \mathrm{H}_{2} \mathrm{O}_{2}$ was added in aliquots with warming until the effervescence was normal or until the general sample 
appearance was unchanged. After cooling, the digest was removed by filtration and allowed to settle. After that, the sample was transferred in to $100 \mathrm{ml}$ volumetric flask and volume was made up to the mark with distilled water. For the reduction of $\mathrm{As}^{\mathrm{V}}$ to $\mathrm{As}^{\mathrm{III}}, 1$ $\mathrm{ml}$ mixture $(5 \% \mathrm{w} / \mathrm{v})$ of $\mathrm{KI}$ and ascorbic acid was added to $1 \mathrm{ml}$ of aliquot. The hydride of arsenic $\left(\mathrm{AS}_{3} \mathrm{H}_{3}\right)$ was generated using sodium borohydrate and $\mathrm{HCl}$. The total arsenic content in soil and plant was determined by flow injection hydride generation atomic absorption spectroscopy (FI-HG-AAS), using a Varian Model AA 55B instrument. The same procedure (without digestion) was followed for the analysis of water samples.

Plant analysis: A sub-sample weighing $0.5 \mathrm{~g}$. was transferred into a dry clean digestion vessel. Five ml of $\mathrm{HNO}_{3}$ was added and then the sample was allowed to stand for over night in a fume hood. In the following day, the vessels were placed on heating block and heating was continued for 2-4 hour as the temperature was slowly raised to $120^{\circ} \mathrm{C}$. When brown fumes were observed, this step (by adding concentrated $\mathrm{HNO}_{3}$ ) was repeated until no brown fumes were given off. There after the vessel was allowed to cool and $3 \mathrm{ml}$ of $30 \% \mathrm{H}_{2} \mathrm{O}_{2}$ was added. Again, the vessel was heated at $120^{\circ} \mathrm{C}$ until the effervescence was minimal. After cooling, the digest was removed by filtration, by centrifugation, or by allowing the sample to settle.

Statistical analysis: The collected data were analyzed statistically following MSTAT-C program.

\section{Results and Discussion}

Yield and yield components: There was no significant variation in yield and yield components among the tested wheat varieties despite of arsenic contamination in the irrigation water and soil (Tables 2-6). In case of first year (2010-11), the experiment was conducted in Benerpota, Satkhira (AEZ 13) and Poranpur, Faridpur (AEZ 12). But arsenic content in soil $\left(6.8 \mathrm{mg} \mathrm{kg}^{-1}\right)$ at Benerpota was much lower than the thresh hold level (20 mg kg ${ }^{-1}$ ) (Duxbury and Zavala 2005) while STW irrigation water (0.14 $\left.\mathrm{mg} \mathrm{L}^{-1}\right)$ contains slightly higher arsenic than recommended safe level $\left(0.10 \mathrm{mg} \mathrm{L}^{-1}\right)$. After completion of the first year trial, the location Benerpota was dropped for the second year trial because of the low arsenic content in soil. However, in case of second year (201112), the trail was conducted in highly arsenic contaminated areas like Sharsha and Chowgacha under Jessore (AEZ 11) in addition to Poranpur of Faridpur.

At Benerpota, Shatkhira during 2010-2011 the grain yield of the tested wheat varieties varied from 3.23 to $3.54 \mathrm{t} \mathrm{ha}^{-1}$ but this variation was statistically non-significant (Table 2). Nevertheless, numerically the highest grain yield $\left(3.54 \mathrm{t} \mathrm{ha}^{-1}\right)$ was recorded from the variety, BARI Gom-21 (Shatabdi), which was followed by BARI Gom-24 (Prodip). Shatabi produced 4, 5 and 9\% higher grain yield than Prodip, Bijoy and BARI Gom-26, respectively. Almost similar trend of result was observed in case of straw yield where yield varied from 3.05 to $3.48 \mathrm{tha}^{-1}$. 
Screening out of wheat varieties

Table 2. Performance of wheat varieties to arsenic contaminated soil and irrigation water at Benerpota, Satkhira during 2010-11.

\begin{tabular}{|c|c|c|c|c|c|c|}
\hline \multirow[t]{2}{*}{ Varieties } & \multirow{2}{*}{$\begin{array}{l}\text { Plant } \\
\text { height } \\
(\mathrm{cm})\end{array}$} & \multirow{2}{*}{$\begin{array}{c}\text { Spike } \\
\mathrm{m}^{-2}\end{array}$} & \multirow{2}{*}{$\begin{array}{c}\text { Grains } \\
\text { spike }^{-1} \\
\text { (no) }\end{array}$} & \multirow{2}{*}{$\begin{array}{c}1000 \\
\text { grains } \\
\text { weight (g) }\end{array}$} & \multicolumn{2}{|c|}{ Yield $\left(\mathrm{t} \mathrm{ha}^{-1}\right)$} \\
\hline & & & & & Grain & Straw \\
\hline $\begin{array}{l}\text { BARI Gom-21 } \\
\text { (Shatabdi) }\end{array}$ & 89.2 & 319 & 39.3 & 47.1 & 3.54 & 3.33 \\
\hline $\begin{array}{l}\text { BARI Gom-23 } \\
\text { (Bijoy) }\end{array}$ & 88.7 & 310 & 40.0 & 47.3 & 3.36 & 3.11 \\
\hline $\begin{array}{l}\text { BARI Gom-24 } \\
\text { (Prodip) }\end{array}$ & 89.5 & 311 & 41.8 & 48.2 & 3.41 & 3.48 \\
\hline BARI Gom-26 & 87.6 & 305 & 38.8 & 47.0 & 3.23 & 3.05 \\
\hline $\begin{array}{l}\text { Level of } \\
\text { significance }\end{array}$ & NS & NS & NS & NS & NS & NS \\
\hline CV $(\%)$ & 2.5 & 3.1 & 6.5 & 2.5 & 11.4 & 8.2 \\
\hline
\end{tabular}

NS $=$ Non significant

In case of Poranpur, Faridpur the highest grain yield (3.62 $\left.\mathrm{t} \mathrm{ha}^{-1}\right)$ was obtained from BARI Gom-24 (Prodip), which was followed by followed by BARI Gom-23 (Bijoy). The lowest grain yield (3.14 $\mathrm{tha}^{-1}$ ) was observed in BARI Gom- 26, which was almost similar to BARI Gom-21 (Shatabdi). Thus the variety, Prodip gave 4, 10 and 15\% higher grain yield than Bijoy, Shatabdi and BARI Gom-26, respectively but such variation was statistically non-significant (Table 3). For the second year (2011-12) too, none of the tested five varieties gave significantly higher yield. Besides, numerically higher grain yield (3.41 t ha ${ }^{-1}$ ) was obtained from BARI Gom-21 (Shatabdi) followed by Prodip (3.34 tha $\left.{ }^{-1}\right)$. Almost similar trend of result was obtained from the straw yield but on an average, the straw yield was $5 \%$ lower than that of the grain yield (Table 4 ).

Table 3. Performance of wheat varieties to arsenic contaminated soil and irrigation water at Poranpur, Faridpur during 2010-11.

\begin{tabular}{|c|c|c|c|c|c|c|}
\hline \multirow[t]{2}{*}{ Varieties } & \multirow{2}{*}{$\begin{array}{l}\text { Plant } \\
\text { height } \\
(\mathrm{cm})\end{array}$} & \multirow{2}{*}{$\begin{array}{l}\text { Spike } \\
\mathrm{m}^{-2}\end{array}$} & \multirow{2}{*}{$\begin{array}{l}\text { Grains } \\
\text { spike }^{-1} \\
\text { (no) }\end{array}$} & \multirow{2}{*}{$\begin{array}{c}1000 \\
\text { grains } \\
\text { weight }(\mathrm{g})\end{array}$} & \multicolumn{2}{|c|}{ Yield $\left(\mathrm{t} \mathrm{ha}^{-1}\right)$} \\
\hline & & & & & Grain & Straw \\
\hline $\begin{array}{l}\text { BARI Gom-21 } \\
\text { (Shatabdi) }\end{array}$ & 87.0 & 317 & 42.3 & 47.6 & 3.28 & 3.42 \\
\hline $\begin{array}{l}\text { BARI Gom-23 } \\
\text { (Bijoy) }\end{array}$ & 88.8 & 321 & 37.5 & 48.2 & 3.49 & 3.26 \\
\hline $\begin{array}{l}\text { BARI Gom-24 } \\
\text { (Prodip) }\end{array}$ & 89.3 & 320 & 38.6. & 47.9 & 3.62 & 3.47 \\
\hline BARI Gom-26 & 86.5 & 308 & 37.3 & 47.7 & 3.14 & 3.07 \\
\hline $\begin{array}{l}\text { Level of } \\
\text { significance }\end{array}$ & NS & NS & NS & NS & NS & NS \\
\hline $\mathrm{CV}(\%)$ & 1.9 & 5.5 & 6.4 & 2.2 & 9.6 & 7.2 \\
\hline
\end{tabular}

NS = Non significant 
Table 4. Performance of wheat varieties to arsenic contaminated soil and irrigation water at Poranpur, Faridpur during 2011-12.

\begin{tabular}{|c|c|c|c|c|c|c|}
\hline \multirow[t]{2}{*}{ Varieties } & \multirow{2}{*}{$\begin{array}{l}\text { Plant } \\
\text { height } \\
(\mathrm{cm})\end{array}$} & \multirow[t]{2}{*}{ Spike $\mathrm{m}^{-2}$} & \multirow{2}{*}{$\begin{array}{c}\text { Grains } \\
\text { spike }^{-1} \\
\text { (no) }\end{array}$} & \multirow{2}{*}{$\begin{array}{l}1000 \text { grains } \\
\text { weight (g) }\end{array}$} & \multicolumn{2}{|c|}{ Yield $\left(\mathrm{t} \mathrm{ha}^{-1}\right)$} \\
\hline & & & & & Grain & Straw \\
\hline $\begin{array}{l}\text { BARI Gom-21 } \\
\text { (Shatabdi) }\end{array}$ & 87.4 & 293 & 38.8 & 47.0 & 3.41 & 3.06 \\
\hline $\begin{array}{l}\text { BARI Gom-23 } \\
\text { (Bijoy) }\end{array}$ & 85.5 & 288 & 40.4 & 46.3 & 3.16 & 3.12 \\
\hline $\begin{array}{l}\text { BARI Gom-24 } \\
\text { (Prodip) }\end{array}$ & 85.0 & 285 & 38.0 & 48.3 & 3.34 & 3.15 \\
\hline BARI Gom-25 & 85.2 & 284 & 38.7 & 46.0 & 3.20 & 3.24 \\
\hline BARI Gom-26 & 86.3 & 291 & 39.3 & 45.6 & 3.25 & 2.98 \\
\hline Level of significance & NS & NS & NS & NS & NS & NS \\
\hline $\mathrm{CV}(\%)$ & 2.1 & 1.6 & 6.1 & 2.6 & 10.3 & 8.7 \\
\hline
\end{tabular}

NS = Non significant

In case of Chowgacha, Jessore the grain yield of the tested wheat varieties ranged from $2.93-3.20 \mathrm{tha}^{-1}$ showing apparently higher result for Shatabdi but this variation was too small to be significant (Table 5).

At the second location, Sharsha under the same district, almost similar trend of result was observed. Numerically, the higher grain yield $\left(3.23 \mathrm{t} \mathrm{ha}^{-1}\right)$ was obtained from Shatabdi followed by Prodip (3.18 $\mathrm{t} \mathrm{ha}^{-1}$ ) and BARI Gom-25 (Table 6).

Table 5. Performance of wheat varieties to arsenic contaminated soil and irrigation water at Chowgacha, Jessore during 2011-12

\begin{tabular}{|c|c|c|c|c|c|c|}
\hline \multirow[t]{2}{*}{ Varieties } & \multirow{2}{*}{$\begin{array}{l}\text { Plant } \\
\text { height } \\
(\mathrm{cm}) \\
\end{array}$} & \multirow{2}{*}{$\begin{array}{l}\text { Spike } \\
\mathrm{m}^{-2}\end{array}$} & \multirow{2}{*}{$\begin{array}{c}\text { Grains } \\
\text { spike }^{-1} \\
\text { (no) }\end{array}$} & \multirow{2}{*}{$\begin{array}{c}1000 \\
\text { grains } \\
\text { weight (g) }\end{array}$} & \multicolumn{2}{|c|}{ Yield $\left(\mathrm{t} \mathrm{ha}^{-1}\right)$} \\
\hline & & & & & Grain & Straw \\
\hline $\begin{array}{l}\text { BARI Gom-21 } \\
\text { (Shatabdi) }\end{array}$ & 87.7 & 289 & 44.7 & 46.0 & 3.20 & 2.95 \\
\hline BARI Gom-23 (Bijoy) & 86.8 & 286 & 41.9 & 46.3 & 3.06 & 2.91 \\
\hline $\begin{array}{l}\text { BARI Gom-24 } \\
\text { (Prodip) }\end{array}$ & 86.7 & 284 & 42.9 & 45.7 & 3.12 & 3.07 \\
\hline BARI Gom-25 & 87.4 & 288 & 43.6 & 45.7 & 2.93 & 3.16 \\
\hline BARI Gom-26 & 86.9 & 290 & 43.7 & 44.8 & 3.03 & 3.01 \\
\hline Level of significance & NS & NS & NS & NS & NS & NS \\
\hline CV(\%) & 2.4 & 1.8 & 5.0 & 3.7 & 9.8 & 10.2 \\
\hline
\end{tabular}

NS = Non significant 
Table 6. Performance of wheat varieties to arsenic contaminated soil and irrigation water at Sharsha, Jessore during 2011-12.

\begin{tabular}{|c|c|c|c|c|c|c|}
\hline \multirow[t]{2}{*}{ Varieties } & \multirow{2}{*}{$\begin{array}{c}\text { Plant } \\
\text { height }(\mathrm{cm})\end{array}$} & \multirow{2}{*}{$\begin{array}{l}\text { Spike } \\
\mathrm{m}^{-2}\end{array}$} & \multirow{2}{*}{$\begin{array}{l}\text { Grains } \\
\text { spike }^{-1} \\
\text { (no) }\end{array}$} & \multirow{2}{*}{$\begin{array}{c}1000 \\
\text { grains } \\
\text { weight }(\mathrm{g})\end{array}$} & \multicolumn{2}{|c|}{ Yield $\left(\mathrm{t} \mathrm{ha}^{-1}\right)$} \\
\hline & & & & & Grain & Straw \\
\hline $\begin{array}{l}\text { BARI Gom-21 } \\
\text { (Shatabdi) }\end{array}$ & 89.4 & 304 & 46.7 & 46.2 & 3.23 & 3.09 \\
\hline $\begin{array}{l}\text { BARI Gom-23 } \\
\text { (Bijoy) }\end{array}$ & 86.9 & 295 & 43.6 & 43.7 & 2.96 & 3.02 \\
\hline $\begin{array}{l}\text { BARI Gom-24 } \\
\text { (Prodip) }\end{array}$ & 86.2 & 296 & 44.3 & 46.0 & 3.18 & 2.92 \\
\hline BARI Gom-25 & 88.2 & 300 & 42.5 & 47.4 & 3.03 & 2.81 \\
\hline BARI Gom-26 & 87.1 & 304 & 43.4 & 46.7 & 2.91 & 2.70 \\
\hline $\begin{array}{l}\text { Level of } \\
\text { significance }\end{array}$ & NS & NS & NS & NS & NS & NS \\
\hline CV(\%) & 2.6 & 2.7 & 3.3 & 4.2 & 8.7 & 7.5 \\
\hline
\end{tabular}

NS = Non significant

Except for Benerpota, as shown in Table 2, the background level of total arsenic in soil was remarkably higher $\left(28.5\right.$ - $\left.36.4 \mathrm{mg} \mathrm{kg}^{-1}\right)$ than the thresh hold level $\left(20 \mathrm{mg} \mathrm{kg}^{-1}\right)$ in addition to excessively higher content of arsenic $\left(0.238\right.$ to $\left.0.346 \mathrm{mg} \mathrm{L}^{-1}\right)$ in the adjacent STW irrigation water as compared to FAO permissible limit $\left(0.10 \mathrm{mg} \mathrm{L}^{-1}\right)$. In spite of these, the tested wheat varieties gave static yield even if not up to their potential but still greatly higher than countries average $\left(3.10 \mathrm{t} \mathrm{ha}^{-1}\right)$ from the major hot spots of arsenic polluted areas like Poranpur, Sharsha and Chowgacha. This result signified that there was no remarkable effect of arsenic contaminated irrigation water and soil on the yield of upland crop like wheat. Under oxidized situation, $\mathrm{As}^{+5}$ (arsenate) becomes the dominant fraction, which is 60 times less toxic than $\mathrm{As}^{+3}$ (arsenite) and that might be the major reason in favor of gaining non significant effect of arsenic contamination on the yield of wheat. These results are in agreement with the findings of Lambkin and Alloway (2003).

Arsenic content and uptake: There was no perceptible variation in arsenic content in wheat among the tested varieties within a particular location irrespective of root, straw and grain (Tables 7-11).

At Benerpota, arsenic content in root varied from 1.21 to $1.88 \mathrm{mg} \mathrm{kg}^{-1}$ where the highest (1.88 mg kg-1) was obtained from BARI Gom-26 followed by Bijoy and the lowest content was in Prodip. Similar trend of result was observed for the contents of arsenic in the straw and grain although they contain much lower arsenic than that of root. The variety, Prodip contains 0.043 and $0.028 \mathrm{mg} \mathrm{kg}^{-1}$ arsenic in straw and grain, respectively, which was lower than the other tested varieties (Table 7). Lower arsenic content (0.010$0.19 \mathrm{mg} \mathrm{kg}-1$ ) in wheat grain was also found in India (Bhattacharya et al. 2010). The total (straw + grain) arsenic uptake was also highest (333 $\mathrm{mg} \mathrm{ha}^{-1}$ ) in BARI Gom-26 followed by Bijoy and the lowest (245 mg kg-1) was in Prodip. The As content in grain was much lower than that of corresponding straw. The transfer coefficient of arsenic from 
soil to above ground parts (straw + grain) of wheat varied slightly among the tested varieties. The highest transfer coefficient (0.0025) was recorded in BARI Gom-26, which means that $0.0025 \%$ of soil arsenic might have transferred to the grain and straw of wheat. However, the lowest transfer coefficient (0.0018) was found in Prodip.

Table 7. Arsenic content and uptake by wheat varieties at Benerpota, Satkhira during 2010-2011.

\begin{tabular}{|c|c|c|c|c|c|c|c|}
\hline \multirow[t]{2}{*}{ Variety } & \multicolumn{3}{|c|}{ Arsenic content $\left(\mathrm{mg} \mathrm{kg}^{-1}\right)$} & \multicolumn{3}{|c|}{ Arsenic uptake $\left(\mathrm{mg} \mathrm{ha}^{-1}\right)$} & \multirow{2}{*}{$\begin{array}{l}\text { Transfer } \\
\text { co-efficient }\end{array}$} \\
\hline & Root & Straw & Grain & Straw & Grain & Total & \\
\hline $\begin{array}{l}\text { BARI Gom- } \\
21 \text { (Shatabdi) }\end{array}$ & 1.42 & 0.056 & 0.032 & 186.48 & 113.28 & 299.76 & 0.0022 \\
\hline $\begin{array}{l}\text { BARI Gom-23 } \\
\text { (Bijoy) }\end{array}$ & 1.65 & 0.061 & 0.036 & 189.71 & 120.96 & 310.67 & 0.0023 \\
\hline $\begin{array}{l}\text { BARI Gom-24 } \\
\text { (Prodip) }\end{array}$ & 1.21 & 0.043 & 0.028 & 149.64 & 95.48 & 245.12 & 0.0018 \\
\hline BARI Gom-26 & 1.88 & 0.068 & 0.039 & 207.4 & 125.97 & 333.37 & 0.0025 \\
\hline
\end{tabular}

At Poranpur, arsenic content in root, straw and grain was much higher than the corresponding values of Benerpota. This might be due to higher level of As in soil and irrigation water in former than that of the latter. The variety, Prodip showed 3.35, 0.164 and $0.086 \mathrm{mg} \mathrm{kg}^{-1}$ arsenic in root, straw and grain, respectively which was lower than rest of the tested varieties (Table 8). The uptake of arsenic was also lowest $\left(880.4 \mathrm{mg} \mathrm{kg}^{-1}\right)$ in Prodip, which resulted in the lower transfer coefficient (0.0015) in it. Similar trend of result (Table 9) was also observed in the second year (2011-12).

Table 8. Arsenic content and uptake by wheat varieties at Paranpur, Faridpur during 2010-2011.

\begin{tabular}{|c|c|c|c|c|c|c|c|}
\hline \multirow[t]{2}{*}{ Variety } & \multicolumn{3}{|c|}{ Arsenic content $\left(\mathrm{mg} \mathrm{kg}^{-1}\right)$} & \multicolumn{3}{|c|}{ Arsenic uptake (mg ha $\left.{ }^{-1}\right)$} & \multirow{2}{*}{$\begin{array}{c}\text { Transfer } \\
\text { co-efficient }\end{array}$} \\
\hline & Root & Straw & Grain & Straw & Grain & Total & \\
\hline $\begin{array}{l}\text { BARI Gom-21 } \\
\text { (Shatabdi) }\end{array}$ & 3.41 & 0.168 & 0.092 & 574.56 & 301.76 & 876.32 & 0.0015 \\
\hline $\begin{array}{l}\text { BARI Gom-23 } \\
\text { (Bijoy) }\end{array}$ & 3.48 & 0.176 & 0.112 & 573.76 & 390.88 & 964.64 & 0.0017 \\
\hline $\begin{array}{l}\text { BARI Gom-24 } \\
\text { (Prodip) }\end{array}$ & 3.35 & 0.164 & 0.086 & 569.08 & 311.32 & 880.4 & 0.0015 \\
\hline BARI Gom-26 & 3.57 & 0.171 & 0.124 & 524.97 & 389.36 & 914.33 & 0.0016 \\
\hline
\end{tabular}

Table 9. Arsenic content and uptake by wheat varieties at Paranpur, Faridpur during 2011-12.

\begin{tabular}{|c|c|c|c|c|c|c|c|}
\hline \multirow[t]{2}{*}{ Variety } & \multicolumn{3}{|c|}{ Arsenic content (mg kg-1) } & \multicolumn{3}{|c|}{ Arsenic uptake (mg ha ${ }^{-1}$ ) } & \multirow{2}{*}{$\begin{array}{c}\text { Transfer } \\
\text { co-efficient }\end{array}$} \\
\hline & Root & Straw & Grain & Straw & Grain & Total & \\
\hline $\begin{array}{l}\text { BARI Gom- } \\
21 \text { (Shatabdi) }\end{array}$ & 3.53 & 0.172 & 0.096 & 526.32 & 327.36 & 853.68 & 0.0015 \\
\hline $\begin{array}{l}\text { BARI Gom-23 } \\
\text { (Bijoy) }\end{array}$ & 3.44 & 0.174 & 0.105 & 542.88 & 331.8 & 874.68 & 0.0015 \\
\hline $\begin{array}{l}\text { BARI Gom-24 } \\
\text { (Prodip) }\end{array}$ & 3.38 & 0.168 & 0.090 & 529.2 & 300.6 & 829.8 & 0.0015 \\
\hline BARI Gom-25 & 3.64 & 0.178 & 0.118 & 576.72 & 377.6 & 954.32 & 0.0017 \\
\hline BARI Gom-26 & 3.60 & 0.183 & 0.120 & 545.34 & 390 & 935.34 & 0.0016 \\
\hline
\end{tabular}


In case of Chowgacha and Sharsha too, the arsenic content, uptake and transfer coefficient values were almost similar to that of Poranpur (Tables 10-11). However, the content and uptake values were narrowly higher for Chowgacha and Sharsha than Poranpur in most of the cases. This might be due to the lower transfer coefficient values in former than the later.

Table 10. Arsenic content and uptake by wheat varieties at Chougacha, Jessore during 2011-12.

\begin{tabular}{lccccccc}
\hline Variety & \multicolumn{3}{c}{ Arsenic content $\left(\mathrm{mg} \mathrm{kg}^{-1}\right)$} & \multicolumn{3}{c}{ Arsenic uptake $\left(\mathrm{mg} \mathrm{ha}^{-1}\right)$} & Transfer \\
\cline { 2 - 6 } & Root & Straw & Grain & Straw & Grain & Total & co-efficient \\
\hline $\begin{array}{l}\text { BARI Gom- } \\
\text { 21 (Shatabdi) }\end{array}$ & 3.48 & 0.186 & 0.102 & 548.70 & 326.40 & 875.10 & 0.0012 \\
$\begin{array}{l}\text { BARI Gom-23 } \\
\text { (Bijoy) }\end{array}$ & 3.56 & 0.178 & 0.098 & 517.98 & 299.88 & 817.86 & 0.0011 \\
$\begin{array}{l}\text { BARI Gom-24 } \\
\text { (Prodip) }\end{array}$ & 3.42 & 0.172 & 0.094 & 528.04 & 293.28 & 821.32 & 0.0011 \\
$\begin{array}{l}\text { BARI Gom-25 } \\
\text { BARI Gom-26 }\end{array}$ & 3.71 & 0.184 & 0.128 & 581.44 & 375.04 & 956.48 & 0.0013 \\
\hline
\end{tabular}

Table 11. Arsenic content and uptake by wheat varieties at Sharsha, Jessore during 2011-12.

\begin{tabular}{|c|c|c|c|c|c|c|c|}
\hline \multirow[t]{2}{*}{ Variety } & \multicolumn{3}{|c|}{ Arsenic content $\left(\mathrm{mg} \mathrm{kg}^{-1}\right)$} & \multicolumn{3}{|c|}{ Arsenic uptake $\left(\mathrm{mg} \mathrm{ha}^{-1}\right)$} & \multirow{2}{*}{$\begin{array}{c}\text { Transfer } \\
\text { co-efficient }\end{array}$} \\
\hline & Root & Straw & Grain & Straw & Grain & Total & \\
\hline $\begin{array}{l}\text { BARI Gom-21 } \\
\text { (Shatabdi) }\end{array}$ & 3.54 & 0.182 & 0.104 & 562.38 & 335.92 & 898.3 & 0.0014 \\
\hline $\begin{array}{l}\text { BARI Gom-23 } \\
\text { (Bijoy) }\end{array}$ & 3.58 & 0.176 & 0.100 & 531.52 & 296 & 827.52 & 0.0013 \\
\hline $\begin{array}{l}\text { BARI Gom-24 } \\
\text { (Prodip) }\end{array}$ & 3.40 & 0.169 & 0.090 & 493.48 & 286.2 & 779.68 & 0.0012 \\
\hline BARI Gom-25 & 3.68 & 0.186 & 0.120 & 522.66 & 363.6 & 886.26 & 0.0014 \\
\hline BARI Gom-26 & 3.62 & 0.180 & 0.123 & 513.00 & 357.93 & 870.93 & 0.0013 \\
\hline
\end{tabular}

Generally, As concentration in roots was about 10 times higher than that in straw. This results suggest that arsenic usually is not distributed to the upper plant parts to a great extent rather mostly accumulates in root. This obtained result might be due to its lower mobility. Such absorption nature of As perhaps escapes the human being as well as cattle from the lethal poisoning. Martin et al. (1993) reported that uptake of arsenic by plants occurs primarily through the root system and the highest concentrations are reported in plant roots and tubers. Similar findings were observed by Kiss et al. (1992) and Tsutsumi (1980).

All the tested wheat varieties under this study appeared as promising and can be grown successfully in the arsenic affected areas. But BARI Gom-24 (Prodip) performed better compared with the other varieties in relation to arsenic content, uptake, biomass yield and transfer coefficient and thus can be regarded as arsenic tolerant to a considerable extent. 


\section{Acknowledgement}

All financial support by PIU- BARC: NATP Phase 1 for conducting this experiment is thankfully acknowledged.

\section{References}

Alam, M.G.M., E.T. Snow and A. Tanaka. 2003. Arsenic and heavy metal contamination of vegetables grown in Samta village, Bangladesh. Science of the Total Environ. 308: 83-96.

Alam, M.G.M., S. Tokunaga and T. Maekawa. 2001. Extraction of arsenic in synthetic arsenic contaminated soil using phosphate. Chemosphere. 43:1035-1041.

BARC. 2005. Fertilizer recommendation guide-2005. Wheat. Bangladesh Agricultural Research Council. Farmgate, Dhaka-1215. 71-72 pp.

Bhattacharya, P., A.C. Samal, J.Majumder and S.C. Santra. 2010. Arsenic contamination in rice, wheat, pulses and vegetables: A study in an arsenic affected area of West Bengal, India.Water Air Soil Pollut. 213:3-13.

Dahal, B.M., M. Fuerhacker, A. Mentler, K.B. Karki, R.R. Shrestha, and W.E.H. Blum. 2008. Arsenic contamination of soils and agricultural plants through irrigation water in Nepal. Environmental Pollution. 155: 157-163.

Das, H.K., A.K. Mitra, P,K. Sengupta, A. Hossain, F. Islam and G.H. Rabbani. 2004. Arsenic concentrations in rice, vegetables and fish in a preliminary study. Environ. Int. 30: 383387.

Duxbury, J.M. and Y.J. Zavala. 2005. What are safe level of arsenic in food and soils? In: Behavior of arsenic in aquifers, soils and plants: Implications for management. Symposium Report. Organized by CIMMYT, Cornell University, Texas A\&M University, United States Geological Survey, and Geological Survey of Bangladesh. Dhaka, January 16-18, 2005.

Duxbury, J.M., A.B. Mayer, J.G. Lauren and N. Hossain. 2003. Food chain aspects of arsenic contamination in Bangladesh: Effects on quality and productivity of rice. J. Environ. Sci. Health 38: 61-69.

Farid, A.T.M., K.C. Roy, K.M. Hossain and R. Sen. 2003. A study of arsenic contaminated irrigation water and its carried over effect on vegetable. In: Fate of Arsenic in the soil environment. BUET-UNU international symposium, Dhaka.113-121.

Kiss, A.M., M. Oncsik, J. Dombovari, S. Veres and G. Acs.1992. Danger of arsenic in drinking and irrigation water to plants and humans. Acta Agron. Hung. 41:3-9

Lambkin, D.C. and B.J. Alloway.2003. Arsenic induced phosphate release from soils and its effect on plant phosphorus. Water Air and Soil Pollution.144 (1):41-56.

Liao, X.Y., T.B. Chen, H. Xie, and Y.R. Liu. 2005. Soil As contamination and its risk assessment in areas near the industrial districts of Chenzhou city, southern China. Environmental. 791-798.

Martin, J L, M. Marchand and A.M.S. Alam. 1993. Assessment of impact and effects of chemical contaminants in aquatic environments. Proceedings of an international symposium on limnology. Department of Botany. Dhaka University. pp 91-96.

Tsutsumi, M. 1980. Intensification of arsenic toxicity to paddy rice by hydrogen sulphide and ferrous iron. I. Induction of bringing and accumulation in rice by arsenic. Soil Sci. Plant. Nutr. 26: 561-569.

Van Green A., Y. Zheng, Z. Cheng, Y. He, R. K. Dhar, J. M. Garnier, J. Rose, A. Seddique, M. A. Hoque and K. M. Ahmed. 2006. Impact of irrigating rice paddies with groundwater containing arsenic in Bangladesh. Sci. of Tot. Env. 367 : 769-777 
Wang, F., Z. Chen, L. Zhang, Y. Gao and Y. Sun. 2006. Arsenic uptake and accumulation in rice (Oryza sativa L.) at different growth stages following soil incorporation of Roxarsone and Arsanilic acid. Plant and Soil. 285 (1-2):359-367.

Yamazaki C., H. Ishiga, F. Ahmed, K. Itoh, K. Suyama and H. Yamamoto. 2003. Vertical distribution of arsenic in Ganges delta sediments in Deuli Village, Bangladesh. Soil Sci Pant Ntr, 49: 567-574.

Zhao F.J., J.L. Stroud, T. Eagling, S.J.Dunham, S.P. McGrath and P.R. Shewry. 2010. Accumulation, distribution, and speciation of arsenic in wheat grain. Environ Sci Technol. 44(14):5464-8.

(Revised copy received on 26-6-2016) 